\title{
EVALUASI PENGGUNAAN ANTIBIOTIK PADA PASIEN PNEUMONIA DI RUMAH SAKIT UMUM DAERAH TULUNGAGUNG
}

\section{EVALUATION OF ANTIBIOTIC USE ON PNEUMONIA PATIENTS IN TULUNGAGUNG REGIONAL HOSPITAL}

\author{
Tsamrotul IImi ${ }^{1}$, Rika Yulia², Fauna Herawati ${ }^{3}$ \\ ${ }^{1}$ Program Studi Farmasi, Universitas Kadiri, Kediri \\ 2 Program Studi Farmasi, Universitas Surabaya, Surabaya \\ 3 Program Studi Farmasi, Universitas Surabaya, Surabaya \\ Penulis Korespondensi: \\ Tsamrotul IImi \\ Universitas Kadiri \\ ilmi@unik-kediri.ac.id
}

\begin{abstract}
ABSTRAK
Pneumonia adalah infeksi jaringan paru yang disebabkan oleh bakteri, jamur, virus atau parasit. Antibiotik merupakan terapi utama pada pneumonia oleh bakteri. Tujuan penelitian ini untuk mengetahui gambaran dan kesesuaian atau ketepatan penggunaan antibiotik pada pasien pneumonia di Rumah Sakit Umum Daerah Tulungagung periode Januari-Juni 2017. Metode penelitian observasional, data diambil secara retrospektif dari rekam medis pasien dan data penggunaan antibiotik dari Instalasi Farmasi, kemudian dianalisis secara deskriptif. Hasil penelitian menunjukkan jenis antibiotik terbanyak yang digunakan pada 130 pasien pneumonia unspecified rawat inap non ICU di Ruang Pulmonary adalah levofloxacin IV $(62,71 \%)$, ceftriaxone $(27,21 \%)$, dan cefotaxim (5,67\%). Kesesuaian penggunaan antibiotik berdasarkan pedoman terapi berupa Panduan Praktik Klinik RSUD Dr. Iskak Tulungagung SM Paru 2014, Perhimpunan Dokter Paru Indonesia (PDPI, 2014), Infections Diseases Sociaty of America/American Thoracis Consensus Guidelines on the Managemen of Community-Acquired Pneumonia in Adult (IDSA/ATS, 2014) dan Drug Information Handbook (DIH, 2011) didapatkan hasil penelitian bahwa yang tepat jenis antibiotik 85,38 \%, tepat dosis $100 \%$, tepat frekuensi $100 \%$ dan tepat lama pemberian $42,34 \%$. Penilaian ketepatan penggunaan antibiotik yang rasional berdasarkan rata-rata kriteria 4 tepat adalah sebesar $81,93 \%$.
\end{abstract}

Kata Kunci : antibiotik, 4 tepat, pneumonia 


\section{JURNAL INOVASI \\ FARMASI INDONESIA \\ (JAFI)}

ABSTRACT

Pneumonia is an infection of lung tissue caused by bacteria, fungi, viruses or parasites. Antibiotics is a major therapy on pneumonia by bacteria. The aim of this study was to determine the description and appropriateness or accuracy of the use of antibiotics in pneumonia patients in the Tulungagung regional Hospital for the period January-June 2017. Observational research method with retrospective data retrieval from patient medical record and antibiotic usage data from Pharmacy Installation then analyzed descriptively. The results showed the most types of antibiotics used in 130 patients with nonspecified pneumonia in ICU in the Pulmonary Room were levofloxacin iv $(62.71 \%)$, ceftriaxone (27.21\%), and cefotaxim (5.67\%). The suitability of the use of antibiotics based on therapeutic guidelines in the form of Clinical Practice Guides Dr. Iskak Tulungagung SM Lung 2014, Association of Indonesian Lung Doctors (PDPI, 2014), Infections Diseases Society of America / American Thoracis Consensus Guidelines on the Management of Community-Acquired Pneumonia in Adults (IDSA / ATS, 2014) and the Drug Information Handbook (DIH, 2011) obtained research results that the right type of antibiotic is $85.38 \%$, the right dose is $100 \%$, the right frequency is $100 \%$ and the exact time of administration is $42.34 \%$. The appraisal of the rational use of antibiotics based on an average of 4 criteria was $81.93 \%$.

Keywords: antibiotics, 4 right, pneumonia

\section{PENDAHULUAN}

Salah satu penyakit infeksi yang sering timbul pada semua umur adalah pneumonia (CDC, 2015). Pneumonia merupakan penyebab utama kematian diantara semua kelompok usia dengan 4 juta kematian ( $7 \%$ dari angka kematian total dunia). Proporsi terbesar ialah pada usia anak kurang dari lima tahun dan dewasa lebih dari 75 tahun (Ruuskanen, et al., 2011). WHO dalam laporannya tahun 2016 menyatakan bahwa pneumonia penyebab kematian penyakit menular tunggal terbesar pada anak-anak di seluruh dunia, menyumbang $16 \%$ dari semua kematian anak di bawah usia 5 tahun, menewaskan 920.000 anak-anak pada tahun 2015 (WHO, 2016). Menurut Riset Kesehatan Dasar (Riskesdas) tahun 2013, menunjukkan kecenderungan yang meningkat untuk prevalensi pneumonia pada semua umur dari 2,1\% tahun 2007 menjadi 2,7\% tahun 2013 (Kementrian Kesehatan RI, 2013).

Terapi utama pneumonia yang disebabkan oleh bakteri adalah antibiotik. Peningkatan penggunaan antibiotik banyak dijumpai baik di negara maju maupun negara berkembang. Di negara yang sudah maju 13-37 \% dari seluruh penderita yang dirawat di rumah sakit mendapatkan antibiotik, sedangkan di negara berkembang lebih tinggi yaitu antara 30-80\% (Negara, 2014). Pada tahun 2016 sebuah studi menunjukkan bahwa hingga $30 \%$ dari antibiotik yang diresepkan oleh dokter untuk pasien rawat jalan di Amerika Serikat tidak tepat. CDC (2015) melaporkan hingga 23.000 orang Amerika meninggal dan 2 juta lainnya menjadi sakit karena bakteri resisten antibiotik setiap tahun (Glenza, 2016). Dalam seminar nasional kajian resistensi antibiotik, Siswanto (2014) memaparkan dari hasil AMRIN Study di Indonesia (2005-2008) bahwa sepertiga antibiotik yang diresepkan tanpa indikasi yang jelas dan hanya $21 \%$ antibiotik yang diresepkan secara rasional.

Penggunaan antibiotik secara berlebihan dan tidak rasional menimbulkan berbagai permasalahan dan merupakan ancaman global bagi kesehatan terutama terjadinya resistensi 


\section{JURNAL INOVASI \\ FARMASI INDONESIA \\ (JAFI)}

bakteri terhadap antibiotik. Resistensi antibiotik mengakibatkan pengobatan antibiotik menjadi tidak efektif, peningkatan morbiditas maupun mortalitas pasien dan meningkatnya biaya perawatan kesehatan serta perpanjangan masa sakit di komunitas sehingga resiko penularan semakin besar (Yenny, 2007).

WHO dan Centers for Disease Control and Prevention (CDC) merekomendasikan agar seluruh rumah sakit mengimplementasikan program Antibiotic Stewardship. Program Antibiotic Stewardship merupakan suatu program terkoordinasi secara institusional untuk memperbaiki dan mengukur penggunaan antibiotik secara bijak dengan mempromosikan pemilihan regimen antibiotik, dosis, durasi dan rute pengobatan antibiotik yang optimal sehingga dapat meningkatkan efektivitas terapi dan mengurangi resiko efek samping maupun resiko resistensi antibiotik (CDC, 2015) (Barlam, 2016). Indonesia dalam upaya menekan berkembangnya bakteri resisten antibiotik telah menetapkan beberapa kebijakan terkait hal tersebut, antara lain menetapkan Permenkes No.8 tahun 2015 tentang Program Pengendalian Resistensi Antimikroba (PPRA) di rumah sakit. Berdasarkan peraturan ini setiap rumah sakit di Indonesia harus melaksanakan Program Pengendalian Resistensi Antimikroba secara optimal. Untuk menilai keberhasilan Program Pengendalian Resistensi Antimikroba di rumah sakit diperlukan evaluasi penggunaan antibiotik (Menteri Kesehatan RI, 2015).

Kasus infeksi terbanyak di Rumah Sakit Umum Daerah Tulungagung pada semester pertama tahun 2017 adalah pneumonia sebesar 347 kasus (Pemerintah Kabupaten Tulungagung, 2016). Pemberian antibiotik seharusnya berdasarkan data mikroorganisme dan hasil uji sensitivitasnya akan tetapi karena proses kultur membutuhkan waktu yang lama menyebabkan terapi antibiotik secara empiris merupakan pilihan terapi pertama bagi pasien pneumonia (Departemen Kesehatan RI, 2005) (Pahriyani, 2015). Penggunaan obat termasuk antibiotik secara rasional menurut WHO dan Kementerian Kesehatan (2011) meliputi 9 Tepat dan 1 Waspada yaitu Tepat diagnosis, indikasi, pemilihan obat, dosis, cara pemberian, interval waktu pemberian, lama pemberian, penilaian kondisi pasien dan waspada efek samping obat (Kementerian Kesehatan RI, 2011). Berdasarkan pedoman pelayanan kefarmasian untuk terapi antibiotik penggunaan antibiotik yang bijak dan rasional meliputi pemilihan antibiotik yang tepat sesuai indikasi, penetapan dosis, frekuensi dan lama pemberian antibiotik yang tepat (Kementerian Kesehatan RI, 2011). Oleh karena itu perlu dilakukan penelitian dengan tujuan untuk mengetahui gambaran dan kesesuaian atau ketepatan penggunaan antibiotik pada pasien pneumonia di Ruang Pulmonary Rumah Sakit Umum Daerah Tulungagung.

\section{METODE PENELITIAN}

Metode penelitian observasional bersifat deskriptif dengan pengambilan data secara retrospektif dari rekam medis dan data penggunaan antibiotik Instalasi Farmasi pada pasien pneumonia yang mendapatkan antibiotik dan menjalani rawat inap di Ruang Pulmonary Rumah Sakit Umum Daerah Tulungagung periode Januari-Juni 2017.

\section{Populasi dan Sampel Penelitian}

\section{Populasi}

Semua pasien pneumonia rawat inap non ICU yang mendapatkan antibiotik di Ruang Pulmonary Rumah Sakit Umum Daerah Tulungagung periode Januari-Juni 2017.

2. Sampel

Sampel adalah populasi yang memenuhi kriteria inklusi dan eksklusi. Kriteria inklusi adalah pasien dewasa, pasien dengan atau tanpa uji kultur kuman, pasien dengan atau tanpa penyakit 


\section{JURNAL INOVASI \\ FARIMASI INDONESIA \\ (JAFI)}

penyerta. Kriteria eksklusi adalah pasien dirawat di ICU, pasien pulang paksa dan pasien dengan catatan rekam medis tidak lengkap. Besar sampel dalam penelitian ini adalah keseluruhan sampel yang memenuhi kriteria.

\section{Analisis Data}

Data yang diambil berupa karakteristik pasien pneumonia berdasarkan jenis kelamin dan umur pasien. Evaluasi penggunaan antibiotik meliputi jenis antibiotik yang digunakan, dosis, frekuensi dan lama pemberian antibiotik. Data yang sudah dikumpulkan kemudian dianalisis secara deskriptif berupa persentase dan disajikan dalam bentuk tabel. Evaluasi kesesuian penggunaan antibiotik ditinjau berdasarkan ketepatan pemilihan jenis antibiotik, dosis, frekuensi dan lama pemberian antibiotik berdasarkan pedoman terapi yaitu Panduan Praktik Klinik (PPK) RSUD Dr. Iskak Tulungagung SM Paru 2014, Perhimpunan Dokter Paru Indonesia (PDPI, 2014), Infections Diseases Sociaty of America/American Thoracis Consensus Guidelines on the Managemen of Community-Acquired Pneumonia in Adult(IDSA/ATS, 2014) dan Drug Information Handbook (DIH, 2011). Rumus perhitungan ketepatan penggunaan antibiotik adalah sebagai berikut (Kamal, 2015):

$1 . \%$ tepat jenis obat $=\frac{\text { jumlah } \text { kasus yang tepat obat }}{\text { banyaknya kasus }} \times 100 \%$

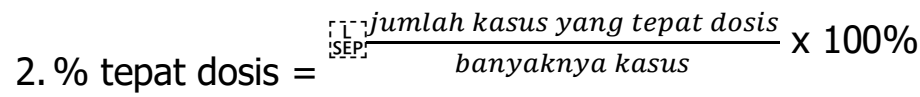

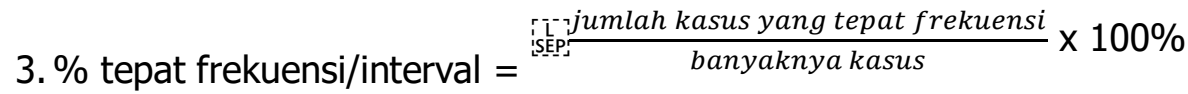

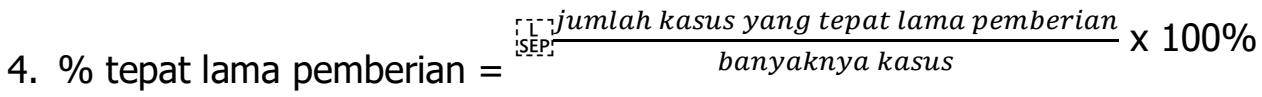

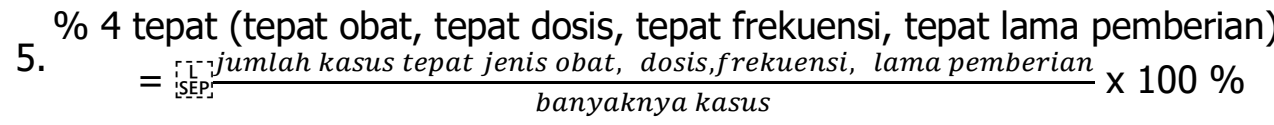

\section{HASIL DAN PEMBAHASAN}

Pasien yang menderita pneumonia rawat inap di Ruang Pulmonary di Rumah Sakit Umum Daerah Tulungagung periode Januari-Juni 2017 terdiagnosa sebagai pneumonia unspecified sebanyak 171 pasien. Berdasarkan kriteria inklusi dan eksklusi terdapat 130 pasien yang masuk subjek penelitian. Penatalaksanaan terapi mengacu pada pneumonia komuniti rawat inap non ICU karena pasien masuk rawat inap terdiagnosa pneumonia atau suspect pneumonia, bukan pneumonia yang didapatkan di rumah sakit.

\section{Karakteristik Pasien Pneumonia}

\section{Berdasarkan Jenis Kelamin}

Berdasarkan jenis kelamin dari 130 pasien terdiri dari pasien laki-laki sebanyak 78 orang (60\%) dan pasien perempuan 52 orang (40\%) seperti pada Tabel $1 .$. 


\section{JURNAL INOVASI \\ FARIMASI INDONESIA \\ (JAFI)}

Tabel 1. Karakteristik Pasien Pneumonia Berdasarkan Jenis Kelamin

\begin{tabular}{ccc}
\hline Jenis Kelamin & Jumlah Pasien & Persentase $(\%)$ \\
\hline Laki-laki & 78 & 60 \\
\hline Perempuan & 52 & 40 \\
\hline Total & 130 & 100
\end{tabular}

Pasien pneumonia lebih sering didapatkan pada laki-laki daripada perempuan disebabkan laki-laki lebih sering beraktivitas di luar rumah, kebiasaan merokok dan juga faktor gaya hidup dan pengaruh lingkungan. Kebiasaan merokok mengubah bentuk jaringan saluran napas dan fungsi silia sebagai penyaring rusak, saluran membengkak dan menyempit (Nugroho et al., 2011). Penelitian lain dengan hasil sama dilakukan di Rumah sakit Nizhny Novogorod Rusia oleh Zhukova et al., (2017) dari 117 pasien pneumonia community-acquired pneumonia (CAP) terdiri dari pasien laki-laki $60 \%$ dan pasien perempuan $40 \%$. Penelitian lain juga menunjukkan hasil serupa dilakukan oleh Elvina et al., (2017) di sebuah RS di Jakarta dan hasil penelitian Farida et al., (2017) di sebuah RS Rujukan Daerah Surakarta.

\section{Berdasarkan Umur}

Berdasarkan analisis terhadap umur pasien diperoleh data, hasil tertinggi pada kelompok umur lansia ( $\geq 65$ tahun) sebanyak $51 \%$ dari 130 pasien (Tabel 2.).

Tabel 2. Karakteristik Pasien Pneumonia Berdasarkan Umur

\begin{tabular}{ccc}
\hline Umur (Tahun) & Jumlah Pasien & Persentase (\%) \\
\hline $20-39$ (muda) & 6 & 5 \\
\hline $40-54$ (dewasa muda) & 20 & 18 \\
\hline $55-64$ (dewasa tua) & 38 & 26 \\
\hline$\geq 65$ (usia lanjut) & 66 & 51 \\
\hline Total & 130 & 100 \\
\hline
\end{tabular}

Keterangan: Batasan umur menurut Badan Pusat Statistika

Hasil ini sesuai dengan pernyatan dari Dhar R (2012) bahwa prevalensi penderita pneumonia meningkat 2-4 kali pada orang dengan usia lebih dari 60 tahun. Hal ini disebabkan karena penurunan sistem imunitas seiring dengan bertambahnya umur, dimulai ketika umur 50 tahun sehingga mudah terjangkit penyakit infeksi. Penurunan fungsi paru dengan pertambahan usia, kelenturan sistem pernapasan menurun akibat peningkatan kekakuan dinding dada mempermudah infeksi saluran napas bawah termasuk pneumonia (Misnadiarly, 2008).

\section{Profil Penggunaan Antibiotik Pada Pasien Pneumonia}

Gambaran penggunaan antibiotik pada pasien pneumonia diperoleh hasil bahwa terdapat tiga jenis antibiotik terbanyak yang digunakan yaitu levofloxacin IV sebesar $62,71 \%$, ceftriaxon sebesar $27,21 \%$ dan cefotaxim sebesar 5,67 \% (Tabel 3.). 


\section{JURNAL INOVASI \\ FARIMASI INDONESIA \\ (JAFI)}

Tabel 3. Gambaran Penggunan Antibiotik Pada Pasien Pneumonia

\begin{tabular}{lc}
\hline \multicolumn{1}{c}{ Nama Antibiotik } & Persentase (\%) \\
\hline Levofloxacin iv & 62,71 \\
\hline Ceftriaxone Inj & 27,21 \\
\hline Cefotaxime Inj & 5,67 \\
\hline Cinam Inj (Ampicilin + & 1,98 \\
Sulbactam) & 1,65 \\
\hline Ciprofloxacin iv & 0,40 \\
\hline Cefadroxil 500mg & 0,20 \\
\hline Meropenem 1g Inj & 0,20 \\
\hline Cefixime 100 mg & 100
\end{tabular}

Levofloxacin termasuk golongan fluorokuinolon jenis baru mempunyai aktivitas spektrum yang lebih luas terhadap kuman gram positif dan gram negatif serta kuman atipik penyebab infeksi saluran nafas bawah termasuk pneumonia. Profil farmakokinetik sangat baik terutama bioavailabilitas yang tinggi dan waktu paruh eliminasi yang panjang. Bentuk oral diserap dengan baik dan beberapa derivatnya tersedia juga dalam bentuk parenteral sehingga dapat digunakan untuk mengatasi infeksi berat (Gunawan, 2007).

Penggunaan levofloxacin IV untuk terapi pada pasien pneumonia sudah sesuai dengan pedoman terapi dan guideline. Penatalaksanaan terapi mengacu pada pneumonia komuniti karena pasien masuk rawat inap terdiagnosa pneumonia atau suspect pneumonia. Berdasarkan Panduan Praktek Klinik RSUD Dr. Iskak Tulungagung SM Paru 2014, Pedoman Diagnosis dan Penatalaksanaan di Indonesia dari PDPI untuk pneumonia komuniti (PDPI, 2014) dan Infectious Diseases Sociaty of America/American Thoracic Society Consensus Guidelines on the Managemen of Community-Acquired Pneumonia in Adults (IDSA/ATS, 2007), penatalaksaan pasien pneumonia komuniti rawat inap non ICU, diberikan fluorokuinolon respirasi yaitu levofloxacin (/evel 1 evidence) atau kombinasi betalaktam dengan makrolid (level 1 evidence).

Hasil penelitian Langtry dan Lamb (1999) menunjukkan bahwa levofloxacin merupakan antibiotik dengan spektrum luas, terdistribusi baik dan mencapai kadar tinggi pada banyak jaringan seperti paru-paru, kulit dan prostat. Bioavailabilitas oral yang tinggi memungkinkan beralih dari intravena ke oral tanpa penyesuaian dosis. Pada pasien pneumonia pemberian levofloxacin intravena dan/oral lebih superior daripada pemberian ceftriaxone intravena dan/atau cefuroxime oral. Penggunaan levofloxacin pada infeksi saluran pernafasan oleh Streptococcus pneumoniae lebih aktif dibandingkan dengan ciprofloxacin atau ofloxacin.

Hasil berbeda ditunjukkan dalam studi lain mengenai evaluasi penggunaan antibiotik pada pasien pneumonia. Hasil penelitian yang dilakukan oleh Pahriyani et al., (2015) di RSUD Budi Asih Jakarta, menunjukkan antibiotik terbanyak yang digunakan adalah seftriakson (52,73\%), demikian juga hasil penelitian oleh Farida et al., (2017) di RS Rujukan Daerah Surakarta antibiotik terbanyak yang digunakan pada pasien pneumonia dewasa adalah seftriakson (66,12 \%). Hal ini tidak sesuai dengan penatalaksaaan terapi berdasarkan pedoman terapi dan guideline, untuk penggunaan seftriakson yang merupan golongan ßlaktam seharusnya dikombinasi dengan makrolida. 


\section{JURNAL INOVASI \\ FARIMASI INDONESIA}

(JAFI)

\section{Kesesuaian atau Ketepatan Penggunaan Antibiotik \\ 1. Ketepatan Pemilihan Jenis Antibiotik}

Penilaian ketepatan pemilihan jenis antibiotik menggunakan standar acuan Pedoman terapi PPK RSUD Dr. Iskak Tulungagung SM Paru Tahun 2014, Pedoman Diagnosis dan Penatalaksanaan di Indonesia dari PDPI untuk pneumonia komuniti (PDPI, 2014) dan Infectious Diseases Sociaty of America/American Thoracic Society Consensus Guidelines on the Managemen of CommunityAcquired Pneumonia in Adults (IDSA/ATS, 2007). Berdasarkan pedoman terapi tersebut penatalaksanaan pasien pneumonia komuniti rawat inap non ICU, pasien diberikan fluorokuinolon respirasi yaitu levofloxacin, moxifloxacin (level 1 evidence) atau kombinasi betalaktam dengan makrolid (level 1 evidence). Ketepatan pemilihan jenis antibiotik pada pasien pneumonia yang dirawat di Ruang Pulmonary didapatkan hasil yang tepat sebanyak 111 pasien (85,38 \%) dan yang tidak tepat sebanyak 19 pasien $(14,62 \%)$ seperti yang terlihat pada Tabel 4 ..

Tabel 4. Ketepatan Pemilihan Antibiotik Berdasarkan Pedoman Terapi

Pemilihan Pedoman Terapi Jumlah Persentase Antibiotik PPK RSUD Dr. Iskak SM Paru Tahun
2014, PPDI (2014) dan IDSA/ATC (2007)

\begin{tabular}{|c|c|c|c|c|}
\hline Levofloxacin iv & \multirow{6}{*}{$\begin{array}{c}\text { Levofloxacin iv } \\
\text { Atau } \\
\text { Betalaktam+ Makrolid }\end{array}$} & 111 & 85,38 & Tepat \\
\hline Ceftriaxone & & 14 & 10,77 & Tidak tepat \\
\hline Cefotaxime & & 1 & 0,77 & Tidak tepat \\
\hline Cinam & & 1 & 0,77 & Tidak tepat \\
\hline Ciprofloxacin iv & & 2 & 1,54 & Tidak tepat \\
\hline Cefixime & & 1 & 0,77 & Tidak tepat \\
\hline & Total & 130 & 100 & \\
\hline
\end{tabular}

Berdasarkan Tabel 4. kategori tidak tepat pada pemilihan antibiotik yakni dengan menggunakan $\beta$-laktam tunggal atau $\beta$-laktam+antibetalaktamase. Penggunaan $\beta$-laktam tunggal tanpa kombinasi dengan makrolida dapat diberikan pada pasien pneumonia rawat jalan (PDPI, 2014), atau pasien CAP yang dirawat non ICU dengan tingkat keparahan yang rendah (British Thoracis Society, 2009). Untuk itu perlu dilakukan pemeriksaan tingkat keparahan terhadap pasien yang terdiagnosa CAP. Hasil penelitian sejenis yang dilakukan Usman et al., (2014) terhadap 29 pasien pneumonia komuniti dengan standar IDSA dan WHO terdapat $31(62,0 \%)$ pasien yang tepat dan 18 (36\%) tidak tepat antibiotik. Penelitian lain oleh Pahriyani et al., (2015) pada pasien CAP non ICU di RSUD Budi Asih Jakarta periode Januari-Maret 2014 dengan standar IDSA/ATS, PDPI dan DIH menunjukkan hasil dari total 42 pasien ketepatan pemilihan jenis antibiotik sebanyak $7,14 \%$.

\section{Ketepatan Dosis Antibiotik}

Hasil penilaian ketepatan pemilihan penggunaan antibiotik pada pasien pneumonia di Ruang Pulmonary adalah levoflxacin IV. Untuk menilai kesesuaian dosis, frekuensi dan lama pemberian antibiotik didasarkan pada jumlah pasien yang sesuai pemilihan jenis antibiotiknya yaitu sebanyak 


\section{JURNAL INOVASI \\ FARIMASI INDONESIA \\ (JAFI)}

111 pasien. Penilaian ketepatan dosis dapat diketahui dengan mengamati dosis levofloxacin yang diberikan pada pasien. Berdasarkan Panduan Praktek Klinik RSUD Dr. Iskak Tulungagung SM Paru, Pedoman PDPI dan IDSA/ATS, pemberian dosis levofloxacin adalah $750 \mathrm{mg}$ setiap 24 jam. Menurut Drug Information of Handbook (DIH, 2011) dosis levofloxacin untuk pneumonia community acquired bisa $500 \mathrm{mg}$ setiap 24 jam untuk 7-14 hari atau dosis $750 \mathrm{mg}$ setiap 24 jam selama 5 hari. Berdasarkan pedoman terapi dan guideline diatas didapatkan hasil bahwa semua pasien yang diberikan terapi levofloxacin mendapatkan dosis antibiotik yang tepat mencapai $100 \%$ (Tabel 5.).

Tabel 5. Ketepatan Dosis Antibiotik Berdasarkan Pedoman Terapi dan Guideline Nama Dosis Dosis Antibiotik Menurut Jumlah Persentase Ketepatan Antibiotik Yang PPK RSUD Dr. Iskak SM Pasien Digunakan Paru Tahun 2014 dan DIH 2011

\begin{tabular}{cccccc}
\hline Levofloxacin IV & $750 \mathrm{mg}$ & $750 \mathrm{mg}$ & 89 & $80,18 \%$ & Tepat \\
\cline { 2 - 6 } & $500 \mathrm{mg}$ & $500 \mathrm{mg}$ & 22 & $19,82 \%$ & Tepat \\
\hline Total & & 111 & $100 \%$ & \\
\hline
\end{tabular}

Dengan pemberian dosis yang sesuai dengan rentang dosis terapi maka efikasi terapi pada pasien juga akan tercapai. Sebuah study clinical trial membandingkan efikasi dan keamanan levofloxacin $750 \mathrm{mg}$ versus $500 \mathrm{mg}$ IV. Hasilnya dapat disimpulkan bahwa regimen levofloxacin $750 \mathrm{mg}$ selama 5 hari sama efektifnya dapat ditoleransi dengan baik sama dengan levofloxacin $500 \mathrm{mg}$ iv selama 7-14 hari untuk terapi pada CAP (Zhao et al., 2014). Hal menguntungkan dari levofloxacin $750 \mathrm{mg}$ adalah durasi penggunaan obat lebih pendek sehingga mempercepat lama penggunaan obat dan lama perawatan di rumah sakit. Penelitian lain yang juga menilai ketepatan dosis antibiotik pada pasien pneumonia komuniti dilakukan di RS Ibnu Sina Makasar (2014) dengan standar IDSA dan WHO sebanyak $31(62,0 \%)$ pasien yang tepat dan $18(36,0 \%)$ pasien tidak tepat dosis antibiotik yang diberikan (Usman, 2014).

\section{Ketepatan Frekuensi Penggunaan Antibiotik}

Hasil penilaian ketepatan frekuensi penggunaan antibiotik pada pasien pneumonia di Ruang Pulmonary didapatkan semua pasien sebanyak 111 orang dikategorikan tepat (100\%) seperti terlihat pada Tabel 6. .

Tabel 6. Ketepatan Frekuensi Penggunaan Antibiotik

\begin{tabular}{|c|c|c|c|c|c|}
\hline Nama Antibiotik & $\begin{array}{c}\text { Frekuensi } \\
\text { Perhari }\end{array}$ & $\begin{array}{l}\text { Guideline } \\
\text { DIH } 2011\end{array}$ & $\begin{array}{l}\text { Jumlah } \\
\text { Pasien }\end{array}$ & Persentase & Ketepatan \\
\hline Levofloxacin 750 mg IV & $1 x$ & \multirow{3}{*}{$\begin{array}{l}\text { Tiap } 24 \\
\text { jam }\end{array}$} & 89 & $80,18 \%$ & Tepat \\
\hline Levofloxacin 500 mg IV & $1 x$ & & 22 & $19,82 \%$ & Tepat \\
\hline \multicolumn{2}{|c|}{ Total } & & 111 & $100 \%$ & \\
\hline
\end{tabular}

Hasil ini sesuai dengan standar Drug Information of Handbook (DIH, 2011) frekuensi atau interval pemberian levofloxacin untuk pneumonia community acquired bisa diberikan $500 \mathrm{mg}$ setiap 24 jam untuk 7-14 hari atau dosis 750 mg setiap 24 jam selama 5 hari. Frekuensi pemberian 


\section{JURNAL INOVASI \\ FARIMASI INDONESIA \\ (JAFI)}

untuk levofloxacin $750 \mathrm{mg}$ maupun $500 \mathrm{mg}$ adalah $1 x$ sehari. Tujuan penyesuaian frekuensi penggunan antibiotik dengan standar adalah untuk menjaga kadar obat dalam darah tetap berada pada rentang indeks terapi, sehingga pengobatan menjadi optimal.

\section{Ketepatan Lama Pemberian Antibiotik}

Penilaian ketepatan lama pemberian antibiotik dalam hal ini pemberian levofloxacin $750 \mathrm{mg}$ berdasarkan IDSA/ATS dan PDPI pada pasien pneumonia komuniti rawat inap non ICU adalah 510 hari. IDSA/ATS juga menyatakan pemberian antibiotik pada pneumonia CAP minimal 5 hari (level 1 evidence). Lama pemberian antibiotik dapat diperpanjang apabila terdapat infeksi ekstraparu (meningitis dan endokarditis). Menurut DIH pada pneumonia community acquired selain pemberian levofloxacin $750 \mathrm{mg}$ pasien juga bisa diberikan levofloxacin $500 \mathrm{mg}$ setiap 24 jam selama 7-14 hari.

Hasil analisis ketepatan lama penggunaan antibiotik didapatkan sebanyak 47 pasien (42.34 \%) tepat dan 64 pasien (57,66 \%) tidak tepat. Dari analisis tersebut juga dapat diketahui bahwa durasi pemberian antibiotik pada pasien pneumonia selama rawat inap di Ruang Pulmonary paling lama adalah 16 hari, paling pendek 1 hari. Pasien yang durasi pemberian antibiotik kurang dari standar sebanyak 60 pasien dan 4 pasien diberikan antibiotik lebih dari standar. IDSA/ATS (2007) menyatakan bahwa kebanyakan pasien menjadi stabil secara klinis dalam waktu 3-7 hari sehingga durasi lebih lama jarang diperlukan namun demikian durasi pendek menjadi kurang optimal. Penelitian serupa dilakukan oleh Usman et al., (2014) pada pasien pneumonia komuniti dengan standar IDSA dan WHO menghasilkan durasi antibiotik sebanyak $29(58,0 \%)$ pasien yang tepat dan $20(40,0 \%)$ pasien tidak tepat. Penelitian lain dilakukan oleh Pahriyani et al., (2015) dengan standar IDSA/ATS dan PDPI menghasilkan ketepatan lama pemberian antibiotik pada pasien pneumonia CAP non ICU sebesar 61,90\%.

\section{KESIMPULAN}

Gambaran penggunaan antibiotik pada 130 pasien pneumonia unspecified rawat inap non ICU di Ruang Pulmonary Rumah Sakit Umum Daerah Tulungagung periode Januari-Juni 2017 adalah levofloxacin IV sebesar $62,71 \%$, ceftriaxon sebesar $27,21 \%$ dan cefotaxim sebesar 5,67 $\%$. Kesesuaian atau ketepatan penggunaan antibiotik berdasarkan pedoman terapi dan guideline yaitu Panduan Praktik Klinik RSUD Dr. Iskak Tulungagung SM Paru Tahun 2014, PDPI (2014), IDSA/ATS (2007) dan DIH (2011), didapatkan hasil yang tepat jenis antibiotik sebesar 85,38 \%, yang tepat dosis sebesar $100 \%$, yang tepat frekuensi sebesar $100 \%$ dan yang tepat lama pemberian sebesar 42,34 \%. Penilaian kesesuaian penggunaan antibiotik yang rasional berdasarkan rata-rata kriteria 4 tepat adalah sebesar $81,93 \%$.

\section{UCAPAN TERIMAKASIH}

Kepada Direktur Rumah Sakit Umum Daerah Tulungagung yang telah bersedia memberi kesempatan untuk melakukan penelitian.

\section{DAFTAR PUSTAKA}

Barlam, T.F., Cosgrove, E., Abbo, L.M., MacDougall, C., Schuetz, A.N. 2016. Implementing an Antibiotic Stewardship Program. Guidline by the Infectious Disease Society of America and the Society for Healthcare Epidemiogy of America. Clinical Infection Disease. IDSA Guideline. 62(10): e51-e77. 


\section{JURNAL INOVASI \\ FARIMASI INDONESIA \\ (JAFI)}

British Thoracis Society. 2009. Guidelines for The Management of Community Acquired Pneumonia in Adults. BMJ Journals. USA. Hal.1-4.

CDC. 2015. Antibiotic / Antimicrobial Resistance CDC. Center for Disease Control and Prevention: 0-2 http://www.cdc.gov/drugresistance/index.html.

CDC. 2015. Core Elements of Hosptal Antibiotic Stewardship Program. http://www.cdc.gov/getsmart/healthcare/core element.pdf.

Departemen Kesehatan RI. 2005. Pharmaceutical Care Untuk Penyakit Infeksi Saluran Pernapasan. Direktorat Bina Farmasi KOmunitas dan Klinik. Direktur Jenderal Bina Kefarmasian dan Alat Kesehatan: 27-32.

Dhar, R. 2012. Pneumonia: Review of Guidelines. Supplement To Japi. 60: 25-29.

Elvina, R., Rahmi, N., Oktavia, S.A. 2017. Evaluasi Penggunaan Antibiotik Pada Pasien CommunityAcquired Pneumonia (CAP) di Instalasi Rawat Inap Rumah sakit "X" Jakarta. Pharmacy. 14(1): 64-74.

Farida, Y., Trisna, A., W, N.D. 2017. Study of Antibiotic Use On Pneumonia Patien In Surakarta Refferal Hospital. Journal of Pharmaceutical Science and Clinical Research. 02: 44-52.

Glenza, J. 2016. Doctors in US incorectly Prescribe Antibiotics in Nearly a Third of Case. Support The Guardian. 2016. Availabel from: theguardian.com/society/2016/may/03/us-antibioticprescription-study.

Gunawan, S.G. 2007. Farmakologi dan Terapi Edisi 5. Jakarta : Departemen Farmakologi dan Terapeutik. FKUI.

IDSA. 2007. Infectious Diseases Sociaty of America/American Thoracic Society Consensus Guidelines on the Managemen of Community-Acquired Pneumonia in Adults. 44: S28-S38.

Kamal, A.M. 2014. Evaluasi Penggunaan Antibiotik Pada Pasien Pneumonia Di RSUD Sukoharjo Tahun 2014. (Skripsi). Fakultas Farmasi Universitas Muhammadiyah Surakarta.

Kementeri Kesehatan RI. 2011. Peraturan Menteri Kesehatan Republik Indonesia Nomor 2406 Tahun 2011 tentang Pedoman Umum Penggunaan Antibiotik.

Kementeri Kesehatan RI. 2015. Peraturan Menteri Kesehatan Republik Indonesia Nomor 8 Tahun 2015 tentang Program Pengendalian Resistensi Antimikroba di Rumah Sakit.

Kementerian Kesehatan Republik Indonesia. 2011. Modul Penggunaan Obat Rasional. Jakarta: 35.

Kementerian Kesehatan Republik Indonesia. 2011. Pedoman Pelayanan Kefarmasian Untuk Terapi Antibiotik. Dirjen Bina Kefarmasian Dan Alat Kesehatan: 1-2.

Kementerian Kesehatan RI. 2013. Riset Kesehatan Dasar 2013. Badan Penelitian Dan Pengembangan Kesehatan.

Langtri, H.D., Lamb, H.M. 1999. Levofloxacin, Its Use Infections of the Respiratory Tract, Skin, Soft Tissues and Urinary Tract. Pubmed.

Misnadiarly. 2008. Penyakit Infeksi Saluran Napas, Pneumonia pada Anak, Orang Dewasa, Usia Lanjut Edisi I. Jakarta: Pustaka Obor Populer.

Negara, K.S. 2014. Analisis Implementasi Kebijakan Penggunaan Antibiotika Rasional Untuk Mencegah Resistensi Antibiotika di RSUP Sanglah Denpasar: Studi Kasus Infeksi Methicillin Resistant Staphylococcus Aureus Analysis The Implementation Policy of Rational Use of Antibiotic. Jurnal ARSI: 42-50.

Nugroho, F., Utami, P.I., Yuniastuti, I. 2011. Evaluasi Penggunaan Antibiotik Pada Penyakit Pnumonia di Rumah Sakit Umum Purbalingga. Jurnal Pharmacy. 08(01): 141-153. 


\section{JURNAL INOVASI \\ FARMASI INDONESIA \\ (JAFI)}

Pahriyani, A., Khotimah, N., Bakar, L. Evaluasi Penggunaan Antibiotik Pada Pasien Comunity Acquired Pneumonia (CAP) di RSUD Budi Asih Jakarta Timur. Farmasains . 2 (6): 259-263.

PDPI Dalam: Pahriyani A, Khotimah N, Bakar L. Evaluasi Penggunaan Antibiotik Pada Pasien Comunity Acquired Pneumonia (CAP) di RSUD Budi Asih Jakarta Timur. Farmasains. 2(6): 259-263.

Pemerintah Kabupaten Tulungagung. Rumah Sakit Umum Daerah Dr.Iskak. 2016. Profil RSUD Dr.Iskak Tulungangung.

Ruuskanen, O., Lahti, E., Jennings, L.C., Murdoch, D.R, 2011. Viral pneumonia. Lancet 377: 126475.

Siswanto. 2014. Kajian Resistensi. In: Seminar Nasional dan Diskusi Interaktif Resistensi Antimikroba. Jakarta: Badan Litbang Kesehatan: 1-3.

Usman, D.A.P., Herman, H., Emelda, A. 2014. Evaluasi Penggunaan Antibiotik Terhadap Pasien Pneumonia Komuniti Di RS Ibnu Sina Makasar. 06 (01): 2085-4714.

$\begin{array}{lllll}\text { World Health } & \text { Organization } & \text { Pneumonia. }\end{array}$ http://www.who.int/mediacntre/factsheets/fs 331/en.

Yenny, Herwana, E. 2007. Resistensi dari Bakteri Enterik: Aspek Global Terhadap Antimikroba. Universa Medicina. 26(1): 46-56.

Zhao, X., Wu, J., Xiu, Q., Wang, C., Zang, D. 2014. A Randomized Controlled Clinical Trial Of Levofloxacin $750 \mathrm{Mg}$ Versus $500 \mathrm{Mg}$ Intravenous Infusion In The Treatment Of CommunityAcquired Pneumonia. Diagnostic Microbiologi and infection Disesae. 80(2): 141-147.

Zhukova, O.V., Ruina, O.V., Kononova, S.V., Konyshkina, T.M. 2017. Analysis Of The Efficiency Of Antimicrobial Treatment For Community-Acquired Pneumonia Clinical Practice. Theraperticheskii Arkhiv. 89(8):17-21. 